\title{
Gambaran EKG pada Individu dengan Kebiasaan Makan Ayam KFC
}

\author{
${ }^{1}$ Ristina R. Sijabat \\ ${ }^{2}$ Shane H. R. Ticoalu \\ ${ }^{2}$ George N. Tanudjaja
}

\author{
${ }^{1}$ Program Studi Pendidikan Dokter Fakultas Kedokteran Universitas Sam Ratulangi Manado \\ ${ }^{2}$ Bagian Anatomi-Histologi Fakultas Kedokteran Universitas Sam Ratulangi Manado \\ Email: ristina.sijabat94@gmail.com
}

\begin{abstract}
Fast food contains high fat and sodium but limited or low nutrients such as calcium, riboflavin, vitamins, magnesium, vitamin $\mathrm{C}$, folate, and fiber; therefore it is classified as poorvegetable food. Excessive consumption of Kentucky fried chicken (KFC), a kind of fast food, can lead to obesity and further to various degenerative diseases such as coronary heart diseases, diabetes mellitus, and hypertension. This study was aimed to obtain the electrocardiography profile of people who used to consume KFC. This was a descriptive study using a cross sectional study. There were 21 subjects in this study. The ECG examination showed that of the 21 subjects, 11 had abnormal ECG result. Conclusion: In this study, half of the subjects showed abnormal ECG.
\end{abstract}

Keywords: fast food, KFC, ECG

\begin{abstract}
Abstrak: Makanan cepat saji (fast food) mempunyai kandungan lemak dan natrium yang cukup tinggi tetapi nilai zat gizinya terbatas atau rendah misalnya: kalsium, riboflavin, vitamin A, magnesium, vitamin $\mathrm{C}$, folat, dan serat; oleh karena itu makanan cepat saji tergolong miskin sayur. Kebiasaan mengonsumsi makanan cepat saji, antara lain Kentucky fried chicken (KFC) secara berlebihan dapat menimbulkan masalah kegemukan yang berkelanjutan akan menimbulkan berbagai macam penyakit degeneratif seperti jantung koroner, diabetes melitus, dan hipertensi. Penelitian ini bertujuan untuk mendapatkan gambaran elektrokardiografi (EKG) pada individu dengan kebiasaan mengonsumsi KFC. Jenis penelitian ini ialah deskriptif dengan desain potong lintang. Hasil pemeriksaan EKG memperlihatkan dari 21 subyek penelitian didapatkan 11 orang dengan hasil EKG tidak normal. Simpulan: Separuh dari subyek penelitian memperlihatkan gambaran EKG yang abnormal.
\end{abstract}

Kata kunci: makanan cepat saji, KFC, EKG

Makanan cepat saji (fast food) merupakan makanan yang disiapkan dalam waktu singkat, juga mengandung zat gizi yang terbatas atau rendah misalnya: kalsium, riboflavin, vitamin A, magnesium, vitamin $\mathrm{C}$, folat, dan serat, tetapi kandungan lemak dan natrium yang cukup tinggi. Makanan cepat saji tergolong makanan yang miskin sayur, dengan menu utamanya ialah daging yang tentu saja berlemak. Ketidakseimbangan zat gizi mulai terjadi ketika makanan cepat saji dijadikan menu utama di rumah atau bahkan dijadikan gaya hidup bagi beberapa orang. Kelebihan kalori, lemak, dan natrium akan terakumulasi di dalam tubuh sehingga dapat menimbulkan berbagai penyakit degeneratif (hipertensi, aterosklerosis, penyakit jantung koroner, dan diabetes melitus). ${ }^{1,2}$

American Heart Associaton menyarankan untuk mengonsumsi 100-150 kalori gula tambahan per hari, yaitu sekitar 6-9 sendok teh per hari, sedangkan kebanyakan makanan cepat saji mengandung 12 ons ( 8 
sendok teh gula) yang setara dengan 130 kalori. Sebagian masyarakat tidak mengetahui efek dari mengonsumsi makanan cepat saji yang berlebihan. Dengan mengonsumsi makanan cepat saji secara terus menerus maka nutrisi penting yang diperlukan oleh tubuh tidak terpenuhi. ${ }^{3}$

Elektrokardiografi (EKG) adalah perekam sinyal jantung dengan keluaran sinyal di monitor dan dicetak pada kertas grafik. Grafik EKG dibentuk oleh gelombang listrik yang mengalir melalui serabut saraf khusus pada jantung. Listrik tersebut dibentuk oleh nodus sinuatria (SA) sebagai sumber primer dan nodus atrio-ventrikular (AV) sebagai cadangan listrik sekunder. $^{4-7}$ Listrik jantung ini dapat pula dibentuk oleh bagian lain dari jantung. Gelombang $\mathrm{P}$ dibentuk oleh aliran listrik yang berasal dari nodus SA di atrium sedangkan kompleks QRS terbentuk oleh aliran listrik di ventrikel, sedangkan PR interval terbentuk ketika aliran listrik tersebut melewati bundle His. Gelombang $\mathrm{T}$ terbentuk ketika terjadi repolarisasi jantung. Arah aliran listrik ini mengarah ke apeks jantung dan sejajar sumbu jantung. ${ }^{6,8}$

Pada penelitian ini, pemeriksaan EKG digunakan untuk pemeriksaan kinerja jantung pada individu dengan kebiasaan mengonsumsi makanan cepat saji.

\section{METODE PENELITIAN}

Jenis penelitian ini ialah deskriptif. Lokasi penelitian berada di Laboratorium Prodia Manado. Subyek penelitian ialah seluruh pengunjung di salah satu restoran KFC Manado, dipilih sesuai dengan kriteria inklusi, kemudian dilakukan pemeriksaan EKG di Laboratorium Prodia Manado. Dalam penelitian ini digunakan kuisioner untuk mempermudah pemilihan subyek penelitian yang memenuhi kriteria inklusi.

\section{HASIL PENELITIAN}

Penelitian ini dilakukan di restoran KFC Megamall Manado dengan subyek berjumlah 32 orang. Karakteristik subyek menurut jenis kelamin memperlihatkan yang berjenis kelamin perempuan lebih banyak daripada laki-laki (Tabel 1). Pemeriksaan EKG memperlihatkan 11 subyek dengan hasil tidak normal (Tabel 2). Distribusi subyek berdasarkan usia memperlihatkan usia terbanyak ialah 30 tahun dan 40 tahun (Tabel 3).

Tabel 1. Distribusi karakteristik subyek penelitian menurut jenis kelamin

\begin{tabular}{ccc}
\hline Jenis kelamin & Jumlah & \% \\
\hline Laki-laki & 12 & 37,5 \\
Perempuan & 20 & 62,5 \\
Total & 32 & 100,0 \\
\hline
\end{tabular}

Tabel 2. Distribusi karakteristik subyek penelitian menurut diagnosis pemeriksaan EKG

\begin{tabular}{ccc}
\hline Hasil EKG & Jumlah & \% \\
\hline Normal & 21 & 65,6 \\
Tidak normal & 11 & 34,4 \\
Total & 32 & 100,00 \\
\hline
\end{tabular}

Tabel 3. Distribusi karakteristik subyek penelitian menurut usia dan jenis kelamin

\begin{tabular}{ccccc}
\hline Usia (tahun) & Jumlah & \% & Laki-laki & Perempuan \\
\hline 30 & 6 & 18,8 & 2 & 4 \\
31 & 4 & 12,5 & 1 & 3 \\
32 & 1 & 3,1 & - & 1 \\
33 & 2 & 6,3 & 1 & 1 \\
34 & 2 & 6,3 & 2 & - \\
35 & 3 & 9,4 & 2 & 1 \\
36 & 4 & 12,5 & - & 4 \\
37 & 2 & 6,3 & 1 & 1 \\
38 & 1 & 3,1 & 1 & - \\
39 & 1 & 3,1 & - & 1 \\
40 & 6 & 18,8 & 3 & 3 \\
Total & 32 & 100,0 & 13 & 19 \\
\hline
\end{tabular}




\section{BAHASAN}

Berdasarkan hasil penelitian didapatkan subyek perempuan sebanyak 20 orang dan subyek laki-laki sebanyak 12 orang (Tabel 1). Usia responden paling banyak pada usia 30 dan 40 tahun masing-masing sebanyak 6 orang, sedangkan jumalh subyek yang paling sedikit ialah pada usia 32, 38, 39 masing-masing sebanyak 1 orang (Tabel 3).

Tabel 2 memperlihatkan hasil pemeriksaan EKG pada subyek penelitian. Didapatkan sebanyak 11 dari 32 subyek $(65,6 \%)$ yang memiliki hasil EKG normal sedangkan 34,4\% dengan hasil EKG yang tidak normal. Kelainan hasil EKG yang diperoleh pada penelitian ini antara lain frekuensi denyut jantung yang tidak normal (frekuensi jantung adalah jumlah denyut jantung selama 1 menit; normal berkisar $60-100 \mathrm{x} /$ menit). Pada penelitian ini yang banyak mengalami kelainan pada hasil EKG terdapat pada subyek berusia 36 tahun hingga 40 tahun; paling banyak ditemukan pada usia 40 tahun. Umumnya subyek penelitian ini cenderung mengarah ke brakikardi

ST elevasi non spesifik terdapat pada subyek yang berusia 35 hingga 40 tahun. ST segmen merupakan segmen waktu antara gelombang QRS dan gelombang T, Penyebab kelainan ST segmen antara lain iskemia dan infark miokardium.

Perbedaan kinerja jantung antara individu yang memiliki kebiasaan makanan cepat saji dan yang tidak memiliki kebiasaan makanan cepat saji tidak begitu terlihat dalam penelitian ini karena penelitian ini hanya menggunakan hasi pemeriksaan EKG namun untuk mengetahui secara spesifik keadaan jantung bisa digunakan beberapa jenis pemeriksaan lainnya yaitu: tes Treadmill, pemeriksaan enzim, ataupun dengan konsultasi ke dokter spesialis jantung. ${ }^{6}$

Beberapa penelitian lain juga menjelaskan bahwa terdapat banyak dampak dari kebiasaan mengonsumsi makanan cepat saji salah satunya yaitu status gizi. Kebanyakan dari mereka memiliki status gizi yang kurang atau berlebihan. Status gizi yang tidak baik merupakan faktor pencetus untuk kinerja jantung yang tidak baik. Hasil tersebut diatas menjelaskan bahwa mengonsumsi makanan cepat saji dengan skala terus menerus akan berdampak yang tidak baik pada kesehatan tubuh. Selain terhadap kinerja jantung, kebiasaan mengonsumsi makanan cepat saji dengan skala secara terus menerus juga berdampak terhadap kejadian obesitas. Seorang ahli gizi mengungkapkan bahwa kebiasaan mengonsumsi makanan cepat saji yang berlebihan kurang baik bagi kesehatan tubuh manusia. Konsumsi makanan cepat saji yang dapat diterima ialah bila frekuensinya 1 kali dalam seminggu; jika lebih dari itu dikatakan tidak baik. ${ }^{9}$

Penelitian lain terhadap makanan cepat saji dan restoran cepat saji telah melaporkan bahwa terdapat hubungan langsung antara jumlah restoran cepat saji yang berada di wilayah lokal dan tingkat obesitas serta beberapa penyakit degeneraif lainnya. Di sisi lain, perlu dicatat bahwa makanan cepat saji juga berbahaya bagi kesehatan akibat kandungan lemak yang tinggi terutama kolesterol, gula dan garam memiliki efek buruk pada kesehatan. Efek jangka pendek bagi yang sering mengonsumsi makanan cepat saji yaitu kurang energi karena makanan cepat saji tidak memberikan nutrisi penting bagi tubuh. ${ }^{9}$

Pada penelitian ini hanya digunakan alat pemeriksaan jantung yaitu EKG. Untuk mendapatkan hasil yang lebih akurat dari kinerja jantung dibutuhkan waktu yang panjang dan pemeriksaan EKG yang berkelanjutan (tidak hanya sekali pemeriksaan) dan pemeriksaan jantung lengkap. Hasil EKG akan mendukung diagnosis penyakit jantung tetapi EKG juga memliki keterbatasan karena tes EKG dilakukan pada waktu pasien sedang istirahat yang umumnya memberikan akurasi sekitar 4050\%. Artinya, bila ada 100 pasien jantung koroner dites dengan pemeriksaan EKG, hasilnya hanya 40-50 orang yang terdeteksi. Selebihnya hanya menunjukkan keadaan normal. Bila tes terlalu dini dihentikan, kemungkinan besar tidak cukup data atau grafik terkumpul untuk 
dibuat interpretasi.

Keterbatasan penelitian ini yaitu kurangnya informasi yang didapatkan dari subyek penelitian tentang aktifitas yang dilakukan setiap harinya, karena hasil pemeriksaan EKG normal kemungkinan karena adanya aktifitas yang cukup berat atau mengeluarkan banyak tenaga sehingga kalori dan lemak yang tidak sehat pun berkurang. Aktifitas tubuh setiap harinya berpengaruh pada kesehatan tubuh secara keseluruhan. Individu yang jarang beraktivitas atau dengan kata lain pekerja kantor yang umumnya hanya bekerja dengan komputer memiliki dampak terhadap suatu penyakit lebih besar dibandingkan dengan yang melakukan aktifitas yang melibatkan pergerakan tubuh.

\section{SIMPULAN}

Berdasarkan hasil penelitian dan bahasan dapat disimpulkan bahwa kebiasaan mengonsumsi makanan cepat saji dapat berdampak negatif pada kinerja jantung. Walaupun demikian hasil pemeriksaan EKG yang normal belum dapat menyingkirkan adanya gangguan pada jantung; untuk itu dibutuhkan pemeriksaan yang lebih lanjut.

\section{SARAN}

Perlu dilakukan penelitian lanjut dengan pemeriksaan yang lebih akurat dan lengkap. Selain itu, perlu dilengkapi dengan mencantumkan aktifitas subyek penelitian setiap harinya untuk memantau pola hidup.

\section{DAFTAR PUSTAKA}

1. Khomsan, Hastuti DT. Komsumsi fast food pada anak remaja. Jurnal Kesehatan. Available from: http://eprints. ums.ac.id. 2008

2. Judarwanto. Makanan jajanan. Jurnal Kesehatan Masyarakat USU. Available from: http://repisitory. usu.ac.id. 2008

3. Ashakiran, Deepthi R. Fastfoods and their impact on health. JKIMSU. 2012;1(2):7-15.

4. Surya D. Sistematika Interpretasi EKG. Jakarta: EGC, 2007.

5. Dharma S. Sistematika Interpretasi EKG: Pedoman Praktis. Jakarta: EGC, 2009.

6. Prakoso R, Harry S. Dasar Interpretasi EKG. Jakarta: Department of Cardiology and Vascular Medicine Faculty of Medicine University of Indonesia, National Cardiovascular Center Harapan Kita, 2011.

7. Sari JSI, editor. Cara kerja fungsi anatomi fisiologi jantung manusia. Semarang: Fakultas Ilmu Keperawatan dan Kesehatan Universitas Muhammadiyah Semarang; 2015/2016.

8. Saparudin, Ramadhan, E. Identifikasi Kelainan Menggunakan Pola Citra Digital Electrocardiogram, Jurnal Generic. 2010;5(1):25-30.

9. Sartika RAD. Faktor risiko obesitas pada anak usia 5-15 tahun. Makara Kesehatan. 2011;15(1):37-43. 